PRINT ISSN 1119-8362

Electronic ISSN 1119-8362
Full-text Available Online at

https://www.ajol.info/index.php/jasem

http://ww.bioline.org.br/ja
J. Appl. Sci. Environ. Manage.

Vol. 25 (5) 829 - 834 May 2021

\title{
Tree Species Diversity and Distribution in the Natural Forest of Onigambari Forest Reserve, Oyo State, Nigeria
}

\section{${ }^{1}$ OLAOTI-LAARO, SO; ${ }^{11}$ TAIWO, DM; ${ }^{1}$ ADENIJI, KA; ${ }^{1}$ ODEWO, SA; ${ }^{2}$ ANIMASHAUN, ZT; ${ }^{1}$ WOGHIREN, AI; ${ }^{2}$ ADEDOYIN, ED}

\author{
${ }^{I *}$ Forest Conservation and Protection Department $;{ }^{2}$ Environmental Modeling and Biometrics Department, Forestry Research Institute of \\ Nigeria, Ibadan, Oyo State, Nigeria \\ *Corresponding Author Email: damilolataiwomary@gmail.com; Tel: +2348167754312
}

\begin{abstract}
Anthropogenic activities has caused depletion of majority of Nigeria forest reserves, reducing forest lands to agricultural lands and grasslands. These prompted this study to consider the diversity of species as well as their species composition in the forest in February 2021. Four sub-plots were established in a cluster with an area of $50 \mathrm{~m}$ by $50 \mathrm{~m}$, with $20 \mathrm{~m}$ distance between each plots and $10 \mathrm{~m}$ as edge effect. Twenty five tree species belonging to fifteen families were found in the study site. Family Malvaceae was the most represented. Triplochiton scleroxylon recorded the highest relative importance value (11.23). The diversity indices across the study plots assessed were species richness, evenness, Shannon index and dominance. Dominance indices across the study plots were low, asides for Plot 4 where. Triplochiton scleroxylon was dominant. Simpson index was highest in Plot 1 and lowest at Plot 4. Shannon index was highest, though in moderation in Plot 1 and relatively low in the remaining plots. Evenness indices across the four plots were high. However, the summarized diversity indices for the study site reflected dominance was generally low, Simpson index was high, Shannon index was moderate and Evenness index was moderate. The dendrogram depicted the relationship among the tree species population based on similarities and dissimilarities. Triplochiton scleroxylon belonged to a cluster while every other species with close similarity were categorized under cluster 2 .
\end{abstract}

\section{DOI: https://dx.doi.org/10.4314/jasem.v25i5.22}

Copyright: Copyright $(0) 2021$ Olaoti-Laaro et al. This is an open access article distributed under the Creative Commons Attribution License (CCL), which permits unrestricted use, distribution, and reproduction in any medium, provided the original work is properly cited.

Dates: Received: 20 March 2021; Revised: 27 April 2021; Accepted: 07 May 2021

Keywords: Anthopogenic activities, trees species diversity, Forest reserve

The impact of human activities on the forest reserves in Nigeria has been extreme. These anthropogenic impacts has turned forest lands to savanna in many ecosystems, hereby leading to loss of biodiversity. Anthropogenic impacts do not only cause a major loss of species, they limit the forest ecosystems from performing their functions too. Furthermore, continued overexploitation depletes the forest environment, endangering the livelihoods of existing users. Local disturbances alter the successional trend and subsequent composition, diversity, and canopy structure of forest ecosystems, according to Oke and Odebiyi (2007). The value of collecting appropriate data for biodiversity evaluation cannot be overstated. The required data obtained from forest reserves is used to formulate policies and prepare for the long-term use and protection of forest resources. A major stumbling block is a lack of adequate knowledge on the degree and significance of biological components in any given ecosystem which is instrumental for the formulation of appropriate policies and the long-term conservation of such ecosystems (Adekunle, 2006). The degradation of Nigeria's lowland forest reserve estates, as well as its genetic and timber resources, through logging and conversion to agricultural plantations, is particularly troubling. According to Adekunle and Olagoke (2007), the greatest force for forest destruction in tropical regions is growing demand for wood and cropland pressure from agriculture which often leads to over-exploitation of the forest reserves. Natural tree stands have been destroyed and fragmented as a result of overexploitation of forest resources. Despite rapid changes in forest composition and structure, there have been few assessments of natural forest reserves in recent years.

This study will include a report on tree species composition and diversity in the Onigambari forest reserve as well as its land use changes (Akinyemi $e t$ al. 2012). This study was conducted in the Onigambari forest reserve in the south-west of Nigeria with the aim of estimating the current tree species composition and diversity as well as making recent and effective conservation recommendations for improved forest management. 


\section{MATERIALS AND METHOD}

Study Site: The Onigambari Forest Reserve is situated between the latitudes $7^{\circ} 81 \mathrm{~N}$ and $7^{\circ} 31 \mathrm{~N}$ and longitude $3^{\circ} 491 \mathrm{E}$ and $3^{\circ} 221 \mathrm{E}$. The forest reserve receives $1337 \mathrm{~mm}$ of cumulative annual rainfall, which is spread out over 114 days of the year and mostly falls between March and October. The average maximum temperature is $26.32^{\circ} \mathrm{C}$, and the average minimum temperature is $21.31^{\circ} \mathrm{C}$ (Larinde and Olasupo, 2011). There is a relative humidity of 74.28 percent. The terrain is relatively flat. On crystalline acid rocks of undifferentiated basement complex gneisses, the soil is ferruginous. The decomposition of underlying schist and quartzite has resulted in a sandy-loam soil that covers the laterites gravels. The reserve is very close to the tropical semi-deciduous rainforest's northern boundary. (Akinyemi et al., 2020).
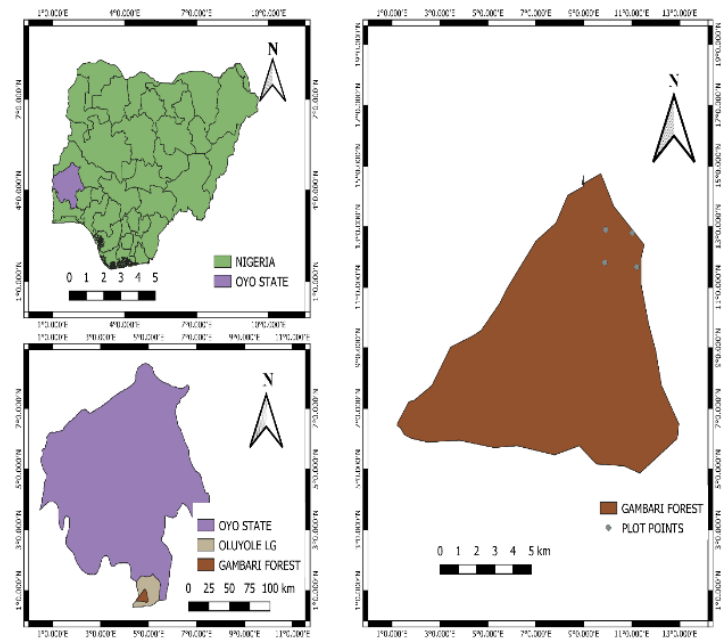

Source: Field Survey (February, 2021)

Plate 1: Map of Onigambari Forest Reserve, Oyo State, Nigeria

Sampling technique: Data was collected in the month of February 2021. Systematic cluster sampling technique was adopted to allocate sample plots. 250 square meter area was partitioned into $50 \times 50 \mathrm{~m}$ tracts. $10 \mathrm{~m}$ distance was considered before laying the plots for the purpose of edge effect. The tracts were $20 \mathrm{~m}$ apart. The clusters were located within the reserve where human interference on the vegetation is relatively low. Four plots were demarcated and located at each corner of the area. In each of the sample plots species composition and abundance was recorded.

Tree Species Identification: The botanical names of every stands encountered in each sub-plot which was equal or above $10 \mathrm{~cm}$ DBH was recorded. Each tree was recorded fully in the field with extra effort made not to omit any eligible tree in a plot.
Method of Data Analysis: The data collected were analyzed for relative importance value (RIV) and diversity indices.

Relative Importance Value (RIV): The Relative Importance Values (RIV) of all species were determined following Olubode et al., 2011. It was computed as:

$$
R I V=\frac{\text { Relative Frequency }}{\text { Relative Density }} \times 100
$$

Where: Frequency: It is the number of occurrence of a species in a set of quadrats or area

Relative Frequency (RF): It is a relative value of occurrence of a species in a set of quadrats to total species in the quadrats.

$$
R F=\frac{\text { Frequency of a species }}{\text { Frequency of other species }} \times 100
$$

Density is the quantity of individual species to abundance of species per unit area.

$$
\text { Density }=\frac{\text { Quantitative values of species }}{\text { Quadrat size / Number of quadrats laid }}
$$

Relative density was obtained using the formula;

$$
R D=\frac{n i}{N} \times 100
$$

Where ni is the number of individual species; $\mathrm{RD}=$ Relative Density; $\mathrm{N}$ is the total number of different species in the entire population

Paleontological statistics software (PAST 2.14) was used to determine species diversity from diversity indices (Hammer et al., 2011). The diversity index analysis took into consideration the following parameters:

Abundance: The quantity or number of each species and family in a quadrat/plot is measured using species abundance (Areghore, 2009)

$$
P_{i}=\frac{\mathrm{Ni}}{\mathrm{N}}
$$

$\mathrm{Ni}$ being the abundance of the i-th species in the sample, and $\mathrm{N}=$ the total number of individuals

Dominance: This is a measure of the prevalence of a particular species in relation to other species in an ecosystem. Dominance shows the species with 
superior competitive ability to others regarded as inferior based on competition (Stephane et al., 2009). It is the most of the population in a community and the effect on any population is mainly influenced by the species of high dominance. It usually ranges from zero to one in value where one signifies high dominance.

Species Richness: It measures the number of different organisms in an ecosystem and their abundance. It depicts a species diversity in a habitat in comparison to the total number of species present. Its value varies from zero to one, with zero indicating low species richness and one indicating total species richness. The method outlined by Spellerberg (1991) and Magurran (2004), as used by Oluwatosin and Jimoh (2016) was used to calculate species richness.

$$
D=\frac{S}{\sqrt[2]{n}}
$$

Where: $\mathrm{D}=$ species richness (Margalef index), $\mathrm{S}=$ the total number of species and $n=$ the total number of individuals.

Evenness: It refers to the number of species per unit area. This was used to measure the similarity of relative abundance of species within sample plots. It was calculated using Pielou's evenness index.

$$
J=\frac{H}{S}
$$

Where J represents Pielou's evenness index, $\mathrm{H}=$ Shannon diversity index and $\mathrm{S}$ is Species richness as previously defined (Hopper et al., 2005)

Shannon Wiener: This is a Claude Shannon-proposed metric that accounts for both the abundance and evenness of organisms in an ecosystem (Olubode et al., 2011). It assesses the overall characteristics of a group. It normally ranges from one to infinity, with two or more indicating a high degree of species randomness in an ecosystem.

$$
H=-\sum_{j=1}^{N} p_{s} \ln p_{s}
$$

Where $\mathrm{H}^{\prime}=$ value of $\mathrm{S}-\mathrm{W}$ diversity index; pi = proportion of individuals in the ith species; $\ln =$ natural logarithm.

$\mathrm{s}=$ Number of species in community

\section{RESULTS AND DISCUSSION}

Species composition and Relative Importance Value of Tree Species in Onigambari Forest Reserve: Out of the one and eleven tree stands encountered during this study among the study plots, twenty five species belonging to fifteen families were recorded. Family Malvaceae was mostly represented amongst other families, this was closely followed by Euphorbiaceae

\begin{tabular}{|c|c|c|c|c|c|c|}
\hline SPECIES & Family & $\begin{array}{l}\text { PLOT } \\
1\end{array}$ & $\begin{array}{l}\text { PLOT } \\
2\end{array}$ & $\begin{array}{l}\text { PLOT } \\
3\end{array}$ & $\begin{array}{l}\text { PLOT } \\
4\end{array}$ & RIV \\
\hline Sterculia macrocarpa G.Don & Malvaceae & 1 & & & & 1.7 \\
\hline Alchornea laxiflora Pax \& K.Hoffm. & Euphorbiaceae & & 1 & & & 1.71 \\
\hline Ficus exasperata Vahl & Moraceae & & & 3 & & 1.72 \\
\hline Lecaniodiscus cupanioides Planch. & Sapindaceae & 1 & & & & 1.72 \\
\hline Sterculia rhinopetala K.Schum. & Malvaceae & 1 & & & & 1.72 \\
\hline Zanthoxylum zanthoxyloides (Lam.) Zepern. \& Timler & Rutaceae & & 1 & & & 1.72 \\
\hline Drypetes floribunda Hutch. & Putranjivaceae & 2 & & & & 2.18 \\
\hline Cola gigantea A.Chev. & Malvaceae & 1 & 1 & & & 2.97 \\
\hline Pinus caribaea Morelet & Pinaceae & & & 4 & & 3.12 \\
\hline Ricinodendron heudelotii (Baill.)Pierre ex Heckel & Euphorbiaceae & 3 & 1 & & & 4.37 \\
\hline Holarrhena floribunda T.Durand \& Schinz & Apocynaceae & 2 & 3 & & & 4.84 \\
\hline Piptadeniastrum africanum (Hook.f.) Brenan & Fabaceae & 2 & & & 3 & 4.84 \\
\hline Cordia millenii Baker & Ehretiaceae & 1 & & 7 & & 6.24 \\
\hline Strombosia pustulata Oliv. & Strombosiaceae & 7 & 1 & & & 6.24 \\
\hline Sterculia tracagantha Lindl. & Malvaceae & 2 & 5 & 2 & & 7.49 \\
\hline Nothospondias staudtii Engl. & Simaroubaceae & 3 & 8 & & & 7.64 \\
\hline Gmelina arborea Roxb. Ex Sm. & Lamiaceae & 2 & & 10 & & 8.11 \\
\hline Triplochiton sceleroxylon K.Schum. & Malvaceae & 4 & 2 & & 10 & 11.23 \\
\hline
\end{tabular}
and Apocynaceae.

Table 1: Abundance and Relative Importance of Tree Species in Onigambari Forest Reserve, 2021

While other families had single species each. Triplochiton scleroxylon had the highest relative importance value (RIV). This was followed by Gmelina arborea, Nothospondias staudtii and 
Sterculia tracagantha, Cordia millenii and Strombosia pustulata in descending order of RIV values. Species with the lowest relative importance values were; Zanthoxylum zanthoxyloides, Scotelia coriacea, Macaranga heudelotii, Lecaniodiscus cupanioides, Ficus exasperate, Aningeria robusta, Alchornea laxiflora and Sterculia macrocarpa.

Species Diversity of Tree Species in the study plots of Onigambari Forest Reserve: The diversity indices for each plots were enumerated separately. Plot 1 was the most diverse, having nineteen species and forty three tree stands. The dominance index was low as expected of a natural forest. The species richness otherwise known as Simpson index was highest in Plot 1 and a moderate diversity index. Plot 2 had low dominance index, high species richness, low diversity index and high evenness index. Plot 3 equally had low dominance index, high species richness and low diversity index. Plot 4 on the other hand had the lowest diversity index, very low species richness, and high dominance index. This can be attributed to the high rate of human interference in Plot 4 and 3.

Table 2: Diversity Indices of Tree Species in the Study Plots of Onigambari Forest Reserve

\begin{tabular}{lllll}
\hline Diversity Indices & PLOT_1 & PLOT_2 & PLOT_3 & PLOT_4 \\
\hline Taxa_S & 19 & 14 & 5 & 2 \\
Individuals & 43 & 29 & 26 & 13 \\
Dominance_D & 0.08 & 0.14 & 0.26 & 0.65 \\
Simpson_1-D & 0.92 & 0.86 & 0.74 & 0.36 \\
Shannon_H & 2.72 & 2.31 & 1.46 & 0.54 \\
Evenness_e^H/S & 0.80 & 0.72 & 0.86 & 0.86 \\
\hline
\end{tabular}

Diversity Indices of the Study Site: This was carried out by summarizing the data from the four plots together. The summarized diversity indices for the study site reflected dominance was generally low, Simpson index was high, Shannon index otherwise known as diversity index was moderate and Evenness index was also moderate.

Table 3: Diversity Indices of the Natural Forest of Onigambari Forest Reserve, 2021

\begin{tabular}{ll}
\hline Diversity Indices & Values \\
\hline Taxa_S & 25 \\
Individuals & 111 \\
Dominance_D & 0.07 \\
Simpson_1-D & 0.93 \\
Shannon_H & 2.84 \\
Evenness_e^H/S & 0.6742 \\
\hline
\end{tabular}

Cluster Dendogram of Tree Species in The Natural Forest of Onigambari Forest Reserve: The dendrogram depicted the relationship among the tree species population based on similarities and dissimilarities (Euclidean distance). The dendogram branched into two major clusters. Cluster 1 and Cluster 2. Cluster 1 comprise mainly of Triplochiton scleroxylon, this means that Triplochiton scleroxylon has a wider range of dissimilarity from the rest of the species found in the study site. Cluster 2 branched into agglomerates of the rest of the species assessed reflecting their similarities. Other species sharing the same links depicted close similarity. Gmelina arborea and Cordia millenii are very similar based on Euclidean distance. Also, Nothospondias staudtii and Sterculia tracagantha, Strombosia pustulata and Celtis zenkeri demonstrated similarity among other species found in the cluster. The rest of the species found having inter-linked branches shared similarities within their groups.

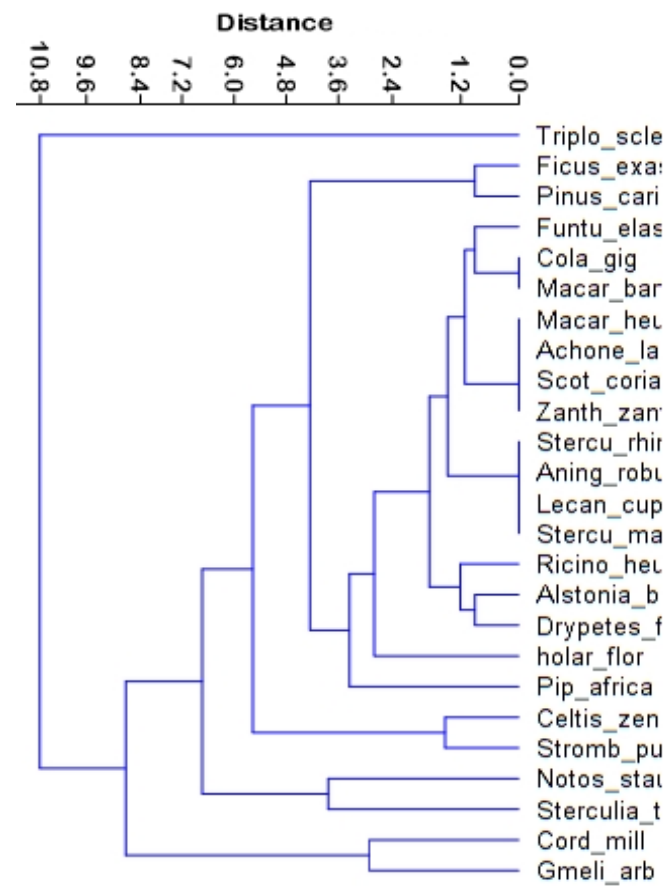

Fig 1: Cluster Dendogram of Tree Species in the Natural Forest of Onigambari Forest Reserve (Note: The names of each species are written out fully in Table 1.)

Deforestation is a major cause of forest loss in Onigambari forest reserve. These, alongside other anthropogenic activities have caused a drastic change in the biological composition of the forest reserve. This study was directed towards understanding the species composition and diversity in the natural forest. Among other species in this study the following species were recorded in the study site: Triplochiton 
scleroxylon, Gmelina arborea, Nothospondias staudtii and Sterculia tracagantha, Cordia millenii and Strombosia pustulata Triplochiton scleroxylon, Gmelina arborea, Nothospondias staudtii and Sterculia tracagantha, Cordia millenii and Strombosia pustulata. Family Malvaceae, Euphorbiaceae and Apocynaceae were the most represented. Triplochiton scleroxylon had the highest relative importance value and it dominated Plot 4 specifically, however, a reduction in the population the tree species was observed, this could be attributed to logging of wood and death of trees in the natural forest. This is in contrast to the report of Akinyemi et al., 2020 and Akinyemi et al., 2012

The diversity indices of different plots highlighted in this study varied, however, it was similar to the diversity indices of the study site. The diversity indices detailed that dominance index was low across the study plots asides Plot 4 where Triplochiton scleroxylon dominated. Species richness on the other hand was high in Plot 1, 2 and 3 and lowest in Plot 4. In addition, the diversity indices was low in the plots except Plot 1 where moderate diversity was recorded, this can be attributed to the adverse effect of loss of tree species to natural causes and logging of wood for fuelwood. The diversity indices for the entire study site summarized the four plots as one. Overall dominance index was very low, while species richness was very high. The evenness index was moderate, while the species diversity was moderate. This is in agreement with Akinyemi et al., 2020 and Salami et al., 2016. The dendogram revealed close associations of species based on their density in the natural forest reserve, with Triplochiton scleroxylon being a 'Standalone-species' (Akinyemi et al., 2020). Other species which reflected close relationship includes Gmelina arborea and Cordia milleniii, Ficus exasperata and Pinus caribaea and Nothospondias staudtii and Sterculia tracagantha.

Conclusion: Despite the continuous logging of trees in the forest reserve for fuel wood, the natural forest has survived through different forms of anthropogenic activities. As negative human impacts, such as grazing within the forest, logging and poaching continues in the natural forest and its surrounding plantations, the species composition and diversity stand a chance of being over-depleted. The moderately diverse natural forest ecosystem needs to be urgently enriched and protected for it to serve ecosystem functions as expected of a secondary regrowth natural forest.

\section{REFERENCES}

Addo-Fordjour, P., Obeng, S., Anning, A. and Addo, M. 2009. Floristic composition, structure and natural regeneration in a moist semi- deciduous forest following anthropogenic disturbances and plant invasion. Inter. J. Biodiver. Conserve. 1 (2):21-37.

Adekunle, V. A. J. 2006. Conservation of tree species diversity in tropical rainforest ecosystem of Southwest Nigeria. J. Forest Sci. 18 (2): 91-101.

Adekunle, V. A. J. and Olagoke, A. O. (2007): Diversity and bio-volume of tree species in natural forest ecosystem in the bitumen-producing area of ondo state, Nigeria: a baseline study. Biodiv. Conserve. 17(11):2735-2755.

Akinyemi, G. O., Ige, P. O. and Smith, A. S. (2012). Evaluation Crown-Diameter Prediction Models for Terminalia superba (Engl. \& Diels) in Onigambari Forest Reserve, Nigeria. J. Forestry Res. Manage. 9: 37- 44 .

Akinyemi, O. D., Taiwo, D. M. Adeoye, O. T. Jeminiwa, O. R. And Olaoti-Laaro, S. O. 2020. Diversity and distribution of tree species in Onigambari forest reserve, South West Nigeria. Ethiopian J. Environ. Stud. Manage. 13(3): 355 363

Aregheore, E. M. 2009. Country pasture/forage resource profiles Nigeria. Food and Agriculture Organization of the United Nations (FAO) Rome Italy Pp 42.

Hammer, O. (2011). Paleontological Statistics Version 2.08. Natural History Museum, University of Oslo. 210ppLykke, A.M. (1998): Assessment of species composition change in savanna vegetation by means of woody plants' size class distributions and local information. Biodiv. Conserve. 7: 1261-1275

Larinde, S. L. and Olasupo, O. (2011). SocioEconomic Importance of Fuelwood Production in Gambari Forest Reserve Area, Oyo State, Nigeria. J. Agric. Soc. Res. 11(1):

Magurran, A. E. 2004: Measuring biological diversity. Blackwell Publishing, Boston. Pp121-126.

Malik Z. A., Hussain A. and Iqbal K. (2014). Species richness and diversity along the disturbance gradient in Kedarnath Wildlife Sanctuary and its adjoining areas in Garhwal Himalaya, India. Inter. J. Cur. Res. 6:10918-10926. 
Neelo, J., Teketay, D., Kashe, K. and Masamba W. (2015): Stand structure, diversity and regeneration status of woody species in open and ex closed dry woodlands sites around molapo farming areas of the Okavango Delta, Northeastern Botswana. Open J. Forestry. 5(4): 313-328.

Oke, D. O. and Odebiyi, K.A. 2007. Traditional cocoabased agroforestry and forest species conservation in Ondo State, Nigeria. Agric. Ecosystems. Environ. 122:305-311.

Olajuigbe, S. O and A. A. Adaja, 2014. Floristic composition, tree canopy structure and regeneration in degraded tropical humid rainforest in southwest Nigeria. Tanzania J. Forestry and Nature Conserve. 84(1): 5-9

Olubode, O. S., Awodoyin R. O., and Ogunyemi S. (2011). Floral Diversity in the wetlands of Apete River, Eleyele Lake and Oba Dam in Ibadan, Nigeria: Its implication for Biodiversity Erosion. West Afr. J. Appl. Ecology. 18: 109-119.
Oluwatosin, B and Jimoh, S. O. (2016). Pattern of plant species diversity in a dry forest ecosystem of Nigeria, J. Forestry Res. Manage. 13: 31-47.

Salami, K. D.; Akinyele, A. O.; Adekola, P. J. and Odewale, M. A. (2016). Tree Species Composition and Regeneration Potential of Onigambari Forest Reserve, Oyo State. Direct Res. J. 4(3): 39-47.

Spellerberg, I. F. (1991). Monitoring Ecological change. New York USA, Cambridge University.112-140pp.

Stephane, B., Richard, C., Philippe, L., Laurent, B. and Frederic, G. 2009. Improving biodiversity indicators of sustainable forest management: Tree genus abundance rather than tree genus richness and dominance for understory vegetation in French lowland Oak Hornbeam forests. Forest Ecology and Manage. 2585: 5176 - 5186.

Sushma S., Zubair A. M., Chandra M. S. (2016): Tree species richness, diversity, and regeneration status indifferent oak (Quercusspp.) dominated forests of Garhwal Himalaya, India;. J. Asia-Pacific Biodiv. 9:293-300. 